Annals of the

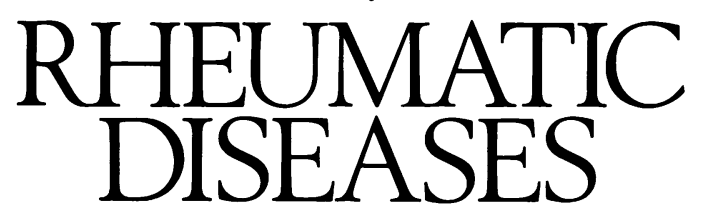

Leader

\title{
Can man's best friend provide clues to the aetiology of systemic lupus erythematosus?
}

It is accepted dogma that genetic and environmental influences are central to the aetiology of systemic lupus erythematosus (SLE) and that the clinical expression of the disease in a given subject will be determined by the relative contributions of each. The clinical heterogeneity, which is so characteristic of SLE, might conceivably be determined predominantly by environmental circumstances. With the exception of drug induced SLE, key environmental influences relevant to most lupus patients remain largely unrecognised. Studies of monozygotic and dizygotic twins have attempted to consider the contribution of the environment to the clinical expression but often seem only to emphasise the genetic influence. ${ }^{1}$ In addition to its presence in man, SLE is well recognised in dogs, ${ }^{23}$ cats, and mice. ${ }^{5}$ SLE-like disorders have also been reported in certain poikilothermic species, such as snakes and iguanas. ${ }^{6}$ The intimate position of the family pet in many households may render our canine friend an ideal subject on which to target research for possible environmental factors.

Canine SLE has received considerable attention since the initial description in 1965, when seven dogs with unequivocal SLE were described. ${ }^{7}$ The features highlighted included malaise, weakness, alopecia, Coomb's positive haemolytic anaemia, thrombocytopenia, membranous glomerulonephritis, and serological abnormalities such as LE cells. It has since been recognised that canine SLE mimics, in virtually every respect, the clinical and immunopathological features of human SLE. ${ }^{8}$ Consequently, naturally occurring canine SLE might be a potentially useful model for research into the aetiopathogenesis of human SLE, contrasting with its murine equivalent, which remains an experimental model. Breeding experiments, using dogs with both clinical and serological evidence of SLE, have shown that genetic mechanisms alone cannot fully explain the aetiology of the disorder. $^{9}$

Although canine SLE has been well defined clinically and pathologically, it appears that many veterinary practitioners may still fail to recognise the disorder. ${ }^{3}$ There is presently no agreement over the criteria for diagnosing canine SLE, and it has been suggested that some veterinarians may be identifying a syndrome which is quite different from the human disease. ${ }^{10}$ Costa et al could only establish canine SLE with certainty in 61/580 dogs in their survey $^{10}$ when the revised American Rheumatological Association criteria for the classification of SLE ${ }^{11}$ were applied.

Evidence that a transmissible factor may be involved in the aetiology of SLE has been sought for over three decades. Initially, the infusion of plasma from patients with SLE into humans with neoplastic disease (but no evidence of SLE) and into normal dogs, leading to the development of LE cells in the recipients, ${ }^{12}$ was considered to be evidence for disease transmission. It was subsequently recognised that this was probably a demonstration of the passive transfer of non-species specific human antinuclear antibodies and not evidence for disease transmission. Intraperitoneal inoculation of a splenic, cell free filtrate from an affected member of an SLE dog colony into four normal newborn beagles, however, resulted in the development of antinuclear antibodies in all recipients within 12 months and these antibodies persisted until the animals were killed at 18 months of age. ${ }^{13}$ Mice receiving similar dog spleen inoculates all developed antinuclear antibodies; some produced specific antibodies to double stranded DNA and some also developed malignant lymphomas containing murine leukaemia virus. Puppies inoculated with cells obtained from these murine lymphomas developed antinuclear antibodies within four months. ${ }^{13}$ Another virus, termed SP104, was isolated from a murine cell line grown from a tumour which had arisen in a murine recipient after inoculation with a cell free splenic filtrate. ${ }^{14}$ Antigenic determinants related to the SP104 virus were identified on the surface of lymphocytes from (human) patients with SLE, ${ }^{14}$ but no SP104 genomic sequences were found in tissues from canine or human patients with SLE. ${ }^{15}$

An infective aetiology for SLE thus remains an attractive hypothesis and a transmissible agent may well be passed between members of a household. A number of viral infections are known to be transmitted reciprocally between man and dog, including reoviruses and adenoviruses. ${ }^{16}$ Interestingly, dog ownership has recently been proposed as a risk factor for scleroderma, again tentatively through an infective aetiology. ${ }^{17}$ Furthermore, paramyxovirus infection of osteoclasts has been proposed as a cause of Paget's disease, and dog ownership has been implicated as a significant risk factor in this association. ${ }^{18}$ The possible role of a transmissible factor which may cross the species barrier has been assessed in a small study of dogs in households containing (human) patients with SLE. ${ }^{19}$ These authors recorded abnormal immunological findings in two dogs of two households containing several lupus patients. Epidemiological studies on subjects exposed to dogs with SLE have not, however, shown an increase in (human) SLE as a consequence of such contact. ${ }^{2021}$ Zambinski et al, however, reported that hospital laboratory staff handling blood 
samples from (human) patients with SLE are more likely to have antibodies to double stranded DNA than those from other laboratory situations. ${ }^{22}$

That factors common to dogs and their owners might be implicated in the aetiology of SLE therefore seems to be a real possibility. A pilot study detecting autoantibodies in the serum of 15 household pet dogs, which had been owned by patients with SLE for many years, has recently been reported. ${ }^{23}$ Assay techniques used in the routine immunopathology laboratory to investigate human SLE were adapted for use with canine serum samples. The dogs owned by patients with SLE had no obvious clinical signs of lupus but had significantly raised levels of antibodies to double stranded DNA and more serum protein electrophoresis abnormalities than a control group of dogs. DNAbinding $\beta$ globulins, normally present in canine serum, can interfere in such assays. ${ }^{20} 24$ These so called 'sticky proteins' can be eliminated by a variety of techniques. ${ }^{23} 25$

Interest in the role of transmissible factors in the aetiology of autoimmune disorders in general, and in particular in SLE, has recently undergone a renaissance with the reports in the international press that Millie, the pet dog of $\mathrm{Mr}$ George Bush, president of the United States of America, has SLE. It will be recalled that both the president and his wife have an autoimmune thyroid disease and our British press certainly latched onto the possible influence of environmental factors. ${ }^{26}$

In the absence of supporting clinical signs positive serology does not make a diagnosis of SLE. However, the ability of environmental factors to lead to the generation of certain autoantibodies seems probable. We have avoided speculation on which transmissible agent or agents may be responsible, but it would seem that the environment can and does have a major role in the development of SLE.

It will not have escaped readers' notice that the wolf is a member of the canine family; maybe there is hidden meaning to the term lupus. In recognition of the marked female preponderance in SLE the title of this article would have been more accurate if it had started as, 'Can woman's best friend......?', but this would not have had the same impact.

Department of Immunology,

Queens Medical Centre,

Nottingham NG7 2UH,

United Kingdom
1 Wallace D J, Dubois E L. Dubois' lupus erythematosus. Philadelphia: Lea and Febiger, 1987.

2 Monier J C, Dardenne M, Rigal D, Costa O, Fournel C, Lapras M. Clinical and laboratory features of canine lupus syndromes. Arthritis Rheum 1980 23: 294-301.

3 Bennett D. Canine systemic lupus erythematosus. In: Grunsell C S, Hill F W, Raw M-E, eds. Veterinary annual. 27th issue. Bristol: Scientechnica, 1987:350-60.

4 Heise S C, Smith R S, Schalm O W. Lupus erythematosus with hemolytic anemia in a cat. Feline Practice 1973; 3: 14-19.

5 Scott D W, Wolfe M J, Smith C A, Lewis R M. The comparative pathology of non-viral bullous skin diseases in domestic animals. Vet Pathol 1980; 17: 257-81.

6 Frye F L. Observations on systemic lupus erythematosus accompanying ymphoreticular neoplasia in poikilothermic species. Theriogenology 1976; 6 : 127-9.

7 Lewis R M, Schwartz R, Henry W B. Canine systemic lupus erythematosus. Blood 1965; 25: 143-60.

8 Lewis R M. Animal model of human disease: canine systemic lupus erythematosus. Am 7 Pathol 1972; 69: 537-40.

9 Lewis R M, Schwartz R S. Canine systemic lupus erythematosus. 7 Exp Med 1971; 134: 417-38.

10 Costa O, Fournel C, Lotchouang E, Monier J C, Fountaine M. Specificities of antinuclear antibodies detected in dogs with systemic lupus erythematosus. Vet Immunol Immunopathol 1984; 7: 369-82.

11 Tan E M, Cohen A S, Fries J F, et al. The 1982 revised criteria for the classification of systemic lupus erythematosus. Arthritis Rheum 1982; 25: 1271-7.

12 Bencze G, Lakatos L, Ludanyi M. Two types of lupus erythematosus cell factor, shown by induced LE cell phenomenon in dogs. BMF 1960; i: 1707-9.

13 Lewis R M, André-Schwartz J, Harris G S, Hirsch M S, Black P H, Schwart\% R S. Canine systemic lupus erythematosus. Transmission of serologic abnormalities by cell-free filtrates. F Clin Invest 1973; 52: 1893-907.

14 Lewis R M, Tannenberg W, Smith C, Schwartz R S. C-type viruses in systemic lupus erythematosus. Nature $1974 ; 252$ : 78-9.

15 Quimby F W, Gebert R, Datta S, et al. Characterization of a retrovirus that cross-reacts serologically with canine and human lupus erythematosus (SLE). Clin Immunol Immunopathol 1978; 9: 194-210.

16 Mayr A. Infektionen, die vom Menscen in Haushalten auf Hund und Katze übertragen werden. (Infections transmitted from man to dogs and cats in the household). Zentralblatt fur Bakteriologie, Mikrobiologie und Hygiene (B) 1989; 86: 508-26.

17 Silman A J, Jones S. Pet ownership: a possible risk factor for scleroderma. $\mathrm{Br}$ 7 Rheumatol 1990; 29: 494 .

18 O'Driscoll J B, Anderson D C. Past pets and Paget's disease. Lancet 1985; ii: 919-21.

19 Beaucher W N, Garman R H, Condemi J J. Familial lupus erythematosus. Antibodies to DNA in household dogs. N Engl $\mathcal{Y}$ Med 1977; 296: 982-4.

20 Clair D, DeHoratius R J, Wolfe J, Halliwell R. Autoantibodies in human contacts of SLE dogs. Arthritis Rheum 1980; 23: 251-3.

21 Reinertsen J L, Kaslow R A, Klippel J H, et al. An epidemiologic study of households exposed to canine systemic lupus erythematosus. Arthritis Rheum 1980; 23: 564-8.

22 Zambiniski M, Messner $\mathrm{R}$ Mandel J Anti-DNA antibodies in technicians handling lupus blood 1-S25. Cincinnati, Ohio, USA: American College of handing lupus blood

23 Jones D R E, Hopkinson N D, Powell R J. Autoantibodies in pet dogs owned by patients with systemic lupus erythematosus (SLE). Lancel. In press.

24 Kristensen S, Flagstad A, Jansen $\mathrm{H}$, et al. The absence of evidence suggesting that systemic lupus erythematosus is a zoonosis of dogs. Vet Rec 1979; 105: 422-3.

25 Thoburn R, Hurvitz A I, Kunkel H G. A DNA-binding protein in the serum Tisdall S. 'Millie on scent of Bush illness'. Guardian 1991 May 25. 